\title{
Women on Hangers
}

\author{
Elizabeth Hay
}

\section{Des femmes sur la corde à linge}

Cette séquence lyrique de saynètes en prose reconstitue la vie de plusieurs femmes et d'un homosexuel vivant dans un quartier à faibles revenues de New York. La narratrice associe pêlemêle des bouts d'histoires de leur vie sous la forme de commérages, des fragments de sa propre vie conjugale et des images tirées de leur vie dans le quartier tout au cours du printemps. Les fleurs de magnolia, Billie Holiday, la violence familiale, le linge suspendu aux cordes à linge sont des thèrnes qui reviennent et gagnent en intensité au cours de cette séquence. 'Contes des cordes à linge ou comment le vide comble les journées. Histoires de femmes'.

In the cupboard blouses retain the smell of beautiful days (as a man who wore shaving lotion once remained on me). Imprisoned in the dark, they remember.

Ilook down and notice for the first time that Cathy wears four rings. Only her hands are visible one floor below as she hangs out clothes.

Cathy is afraid of the subway and can't drive. Yesterday she went as a chaperone with her daughter's school to see the Statue of Liberty. It was beautiful, she said. She didn't climb to the top though. Her hips wouldn't fit.

Her teenage daughter leans out the window. Down the street another girl leans out, and accompanying a cassette, sings into the street - sibilance. Her s's travel farther than she.

In our increasingly yellow cocoons we approach spring. Sealed off, isolated, women put pillows on windowsills to cushion their arms when they lean out.

'And men say the sun and moon keep on moving / because they can't find a soft seat.' Pound went mad on air, women come unpinned. 
'T have no family here,' Clara tells me.

You came by yourself from Italy?'

'By myself. I was 20 years old.'

'An arranged marriage?'

'Yes. Arranged.' She shakes her head, her eyes soft with the imminent possibility of weeping.

'Awful,' she says. 'I'd never recommend it, not even to my worst enemy.'

Two children in less than two years, she lived on the third floor, couldn't go for a quart of milk unless she took both with her. So tired, that once when she was nursing the second baby she felt him sliding out of her arms, powerless to hold him any longer.

'I had no one,' she says.

Your husband, I want to ask - where was he?

Laura tells me. One morning when my daughter and I are in the backyard, she raises the window, rosary in hand. I count the rhinestones in her glasses while I listen.

'She was so pretty when she came over,' says Laura. 'And thin,' holding up her finger to demonstrate. 'With red cheeks,' and she pinches her own. 'They were so mean to her.'

'Her husband?'

'And her mother-in-law. They hit her all the time. The mother-in-law still lives there. 103 years old. She never goes outside, you'll never see her outside.'

Clara-Clelia. 'But no one could pronounce it,' implying with a look that no one wanted to.

Washing on the line. After two days of rain, the only life in the streets.

I listen to the mourning doves. Wait for the light to be just so-before snapping a photo. I want to remember this scene, I like it so much.

Sal did a wash this morning. It was hanging on the line when I looked out at 6:45, the first one he's done in three and a half months. Eighteen shirts and one pair of pants. The shirts like low-income butterflies: bright yellow, purple and white, pink and red, pink and black. I remember seeing him walk down the street in the yellow one.

I wonder if he ever looks over here - his windows face ours. I wonder if he sees me drinking this cup of coffee. 
Sal - the name Jack Kerouac gave himself in On the Road. My appetite awakened by his, I make an apple pie and eat it with vanilla ice cream as he did going west. 'I knew it was nutritious, and it certainly was delicious.'

Sal comes out. He carries a plastic shopping bag as always, but a trench coat has replaced his winter jacket. White moustache, white hair, yellowish streaks. Unshaven, shy.

His mailbox is beside ours.

We approach at the mailman's speed, my daughter's tiny steps, his house-by-house stops, and arrive at Sal's perfume: aftershave despite the lack of one. Heasks the mailman if it's there, and the mailman sorts the mail. 'No.'

'The cheque's not there? That surprises me. It usually comes on the third, and it didn't come yesterday either.'

My daughter and I go inside.

The landlord comes out of Sal's house, turns around in the doorway and shakes his finger at him. It must be the rent.

I saw the Ecuadoran woman this morning. She walked by dressed in fake fur. The one who's beaten all the time, Clara says.

I said to Laura last night, 'I feel so sorry for Hedda Nussbaum.'

Her picture has been in the paper all week. A writer of children's books, a former editor at Random House, her daughter was found beaten to death, Hedda herself 'black and blue' when sheand her husband were brought into court.

'Do you? I don't feel a bit sorry.'

'Why not?'

'I don't have any sympathy for a woman who doesn't defend her children.'

'But she was frightened, beaten.'

And that's when Laura told me that 35 years ago she got a court order against her husband.

On another occasion Clara was there too, and we were discussing divorce which they both oppose. Clara said, 'This world isn't meant for joy, it's meant for suffering.' 
Lawnchairs on the sidewalk, tattoos on men. Women take the airby sitting on the sidewalk; men remain inside watching television, their faces inked with pale blue light.

Clara said of the Ecuadoran woman, When she was pregnant he beat her all the time. Their bed must be right above mine, it's awful.'

Pregnant with the little girl who was killed a month ago. Their car rolled over an embankment into the river, the others escaped but the little girl drowned.

'Her body was black in the coffin, all black.'

Beaten since before she was born.

Why does it make me so uneasy to put clothes into drawers? Especially my daughter's. The suggestion of finality. The end of their life on the line.

We've come back after a few days away, and the closed smell is overpowering. The end of motion - a spillage. Bags, diapers, food, toys. A stopping short that makes me almost nauseous.

The familiar deadened by our absence, we enter our own absence and it's all too familiar. Domestic violence of loneliness, smack of isolation. The future - waiting for us - in a drawer.

'Every time I think of that it makes me feel sad,' Alec says on the phone, 'a little sick inside.'

I know the question without hearing it. When are you going back to Mexico?

'I don't know,' he answers. 'In the fall, I guess.' But he sounds unconvinced, depressed that it won't happen sooner, might not even happen then.

It's been a year and a half since we left, since we packed and unpacked, opened and closed drawers on a difficult ending and a difficult beginning.

The picture haunts me. The first picture Isaw of Hedda. Lips puffed out, nose broken, flattened, bandaged. Her eyes, all of her, beyond crying. The face of a cavewoman beaten backwards into some awful misery. And her husband beside her - strong, vigorous, husky.

Each had been charged with attempted murder, assault, and endangerment of the welfare of their six year old daughter who lay in 
hospital, unconscious, blood on her brain, having been found naked, 'unusually thin,' and not breathing after Hedda Nussbaum called emergency to say her daughter had choked on some vegetables.

Hedda's face stares ahead / down at nothing. Chalky. As though flour has been poured over her features. Humiliated.

A neighbour said, ' $I$ ' ve been here in the building thirteen years and he's been beating her thirteen years.'

'I got a court order,' Laura told me, 'against my husband. My son was about six then.'

'And he stopped?'

'Oh yeah - they put him on probation for six months.'

Louis. The man she's been married to for 47 years. Three years ago he fell down the stairs and went into coma for three months. When he woke up Laura brought him home. They said he would live six months, but here heis. Laura changes his diapers, hoists him in and out of bed, never goes out except to buy food or go to church.

Just as she sits down to eat he gets a gleam in his eye. 'Laura, I want a glass of water.' Or, 'Laura, I just did it.'

And she wheels him into the bedroom, lifts him onto the bed, wipes the shit off his frail, pale, withered haunches and puts on a fresh diaper. The stink fills the apartment. Then she wheels him back to the table, stuffs his pills into his mouth, crams them in with her fingers so that he almost chokes.

Cathy tells me that all last summer Louis accused Laura of having an affair because she would go out in the evening and stand in the street to get some air.

An affair with air.

Sal - six windows. Four of them covered with permanently drawn yellow blinds. Two with curtains and plastic, but perhaps some light penetrates. I've never seen him in any of the windows, and I've seen a light on in only one.

No,' Laura tells me, 'he never raises his blinds except in the summer when it gets really hot.'

'He's in there all day? With the blinds drawn?'

'Oh no. He hangs out at that little restaurant on Graham Avenue 
beside $A B C$ Bargains. He has a friend there, Wally, the busboy-or busman.'

Sal smiled today. He smiled and said hello as I lifted my daughter's stroller into the street. He has never offered a greeting before.

We watch the progress of Clara's magnolia tree. I open the windows hoping for fragrance. It should be an orange scent.

Dark / dim / bright. The motion from inside the bud to its pinkish white surface. My daughter is asleep in the far room, Alec is sick in the middle room, and I' $m$ here, in the kitchen, with a cup of coffee and rain on the magnolia, afraid the blossoms will be disturbed before they open, disturbed but opening in the peacefulness, the quiet. My spot.

Magnolia blossoms tilt towards the east. Cathay.

Last night I went to the Chinese grocer's where the young cashier dips her fingers in half a lemon before riffling open the plastic bags. Stopping there or simply passing gives me such pleasure: oranges, glistening red peppers, flowers illuminated by lightbulbs, an awning, a fair.

Korean, Alec says.

Never mind. Cathay.

Now I know why I've been thinking about Billie Holiday the last couple of days,' says Alec as we listen to her on the radio. 'I was thinking about the interview they played last year; it's been a year.'

An interesting sense of time - to have the buds remind him of Billie, reminded because the radio remembers.

I lean out the window into the perfume of clothes, Cathy's down below. They play a rehearsal session from mid-August, 1955. So drunk. Impossible to make out what she says, sudsy voice.

Snapping her fingers.

Magnolia stems.

She would be 72 .

We talk about whether her voice was better in the thirties and forties, or in the fifties. Whether it was better when it was ragged and haunted but more mature, or younger, fresher, with a happier beat. Alec prefers the older, I the younger. More feeling, he says. But there was plenty of feeling before, and less pain. 
Clothesline stories: how emptiness moves and fills the day. Women's stories.

She died at the age of 44.1959.

Still life - lips. Except when they move: the uncoloured lips of the homeless gray-haired woman, pressed together in sudden laughter suddenly over - tremors that pass uncensored over the face of a newborn, reading her future.

Clara sweeps brown withered petals off the sidewalk. Her husband. Suddenly I think of him. Never seen. Only once when I went to retrieve a towel blown into their yard. I knocked on the apartment door and he opened it. 'Ask my wife,' and he indicated the apartment one door over.

As if to summarize her whole life Clara never hangs out washing unless it's bound to rain. Again today-overcast, an 80 percent chance of rain, and her line is full.

Empty clothes / empty lives. Having drunk the magnolia tree, swallowed its colour, flavour, scent - we read the petals left behind.

On the first hot day in two weeks, the postcard of a Montreal snowstorm falls off the wall. I find it face down on my desk.

Sedna, the Inuit sea goddess, clung to the edge of her brothers' boat until they chopped off her fingers, then sank to the bottom of the sea. Now petals cover the ground like fingertips.

As I fold sheets I'm reminded of my mother folding anger into herself. On hot summer days she would continue to cook with transparent good humour, as though dressed for theoccasion. Her anger-hard stones under an inch of clear water. Orbetter-light on the other side of clothes: clear, barely impeded, lowering so that it comes through sleeves.

Evening light as low as cuffs.

My daughter whines and tugs at my legs until I swear at her and walk away (a clothesline walking away from clothes) into the far room where I shut the door and huddleagainst the wall for a few minutes. It only makes her worse, of course.

Cold today. The magnolia-thin. The tips of Clara's stockings on the line. A neighbourhood down at the heel. 
Sal stands on the sidewalk, Cathy leans out the second floor window.

'Okay, I'll phone,' he says. (I've seen him using a payphone on Graham Avenue.)

'Thank you, Catherine.'

I've never heard anyone else use her full name. He is so bashful, so eager, not to please exactly, just not to offend. He closes the gate and it doesn't catch. Cathy calls after him to close it and he does so hastily, apologetically, with infinite care.

The man who has been carrying things (at the moment a standing tin closet) out of Sal's house has a mouth like a waist, and a waist likea mouth - protruding stomach, no teeth. Igo downstairs and find Laura and Clara in lawnchairs on the sidewalk.

'What's happened to Sal?' I ask.

'Gone. Moved out.'

'Where?'

'A furnished room in Greenpoint.'

'And all his things?'

They're clearing it all away now - he left everything behind almost.'

The mover is Wally. He brings out a big box tied with a string which breaks. Records spill out. Broadway musicals, the theme music to Ben Casey, Oklahoma -

'He was quite a dancer,' Laura says. 'Oh yes. And he sewed all his own costumes. He couldn't read or write - his sister told me - but if somebody had picked him up, some designer, he could have made a fortune.'

'He danced? Where? For money?'

'He used to dance in those places, you know, dressed up.'

'Like a woman?'

Yeah. He made the most beautiful things, sequins and applique. He had hands of gold. Thirteen - fifteen years he's been here. He had a companion, Al, but he died.'

'What's in that wooden box?' she asks Wally.

'His brushes.'

'Oh - he was a painter too,' Laura tells me. 'Beautiful things.'

Lowering her voice, 'Al had a nervous breakdown. Such nice boys. I call them boys, I' $m$ old enough to be their mother. They were together 
since they were kids, and they never gave us a bit of trouble. Never brought anybody back there, never.'

'When did Al die?'

'Let's see. My Lorraine - may she rest in peace - died two months ago, and my sister five months ago. Seven months ago.'

'Why did Sal leave all his things behind?'

'Oh, he'll just have one room.'

Clara adds, When the husband dies, you know ... Do you understand what I mean?'

There are two styles, pinning by the shoulders or the feet. The Oriental woman who lives just beyond pins her clothes by their small bound feet.

Connected by clothes, by the disarming intimacy of ragged underwear between dilapidated buildings. Beautiful connections of colour, shape, motion in the sun.

In clothesline stories, as in radio stories, bodies are invisible. We have to imagine. Clara's bloomers have holes, Cathy's towels are frayed.

Women in this neighbourhood live taped lives, the same every day, over and over again.

Going live. Going taped. Going bandaged.

The tone of trapped things (Billie's tone) forms the music. 